\title{
下肢破壊性関節の治療経験
}

\author{
国立善通寺病院整形外科 \\ 中 野 俊 次. 西庄 武彦 \\ 藤内武春・堀川治
}

\section{Clinical Experience of Destroyed Joints in Lower Extrimities}

by

\section{Syunji Nakano, Takehiko Nishisho, Takeharu Tonai and Osamu Horikawa \\ Department of Orthopaedic Surgery, Zentsuji National Hospital, Kagawa, Japan}

\begin{abstract}
We will present three patients whose gaits were disturbed by destroyed joints in their lower extremities.

There was one case of rheumatoid arthritis of the mutilans type, whose radiographic findings were similar to those of Charcot's joint, The othere two case had Charcot's Joints with destruction of the ankle joint caused by diabetic mellitus in one and destruction of the knee joint by spondyloschisis in the other.

We performed intravenous digital subtraction angiographies (IV-DSA) of both lower extremities on all three cases. The angiografic findings of the two Charcot's joints showed an abnormally rapid venous filling and a tumor-stain-like shadow. In contrast to Charcot's joint, the mutilans RA showed no angiographic abnomalities.

We conclude that an angiographic evaluation is valuable in the diagnosis of Charcot's joint.
\end{abstract}

\section{はじめに}

最近我々は下肢関節が破壞され高度動摇性を呈する ため歩行障害となった 3 症例を経験し，両下肢経静脈 的 Digital subtraction angiography (以下 IVDSA）が Charcot 関節の補助診断として有益であっ たので報告する.

\section{対 象}

対象は神経病性関節症（Charcot 関節）2 例，ム チランス型RA1例であった.

Charcot 関節の原因疾患は脊椎破壊 1 例，糖尿病 1 例であった.

\section{症 例 供 覧}

症例 1, 73 歳 女性 主訴: 歩行障害

現病歴 10 年程前より糖尿病にてインシュリン療 法を受けていた。昨年末左足関節の骨折のため, 某医 で 1 ケ月間ギプス固定をうけ，一時は歩行可能であっ たが，しだいに足関節の変形をきたし立位不能となり 当科へ紹介された，その際の単純レ線では脱臼粉砕骨 折の像を呈していた（図 1)

現症 左足関節変形と不安定性著明で圧痛が軽度あ り, 振動覚・位置覚の深部知覚は低下していた。

両下肢 IV-DSA を施行, 左患側の静脈相の早期出 現, 血管増生の異常所見を認め糖尿病 Charcot 関 節 ${ }^{21}$ と診断した．短下肢ギプス， PTB braceにて治 療し, 歩行可能となった。 2 か月後の単純レ線では足 

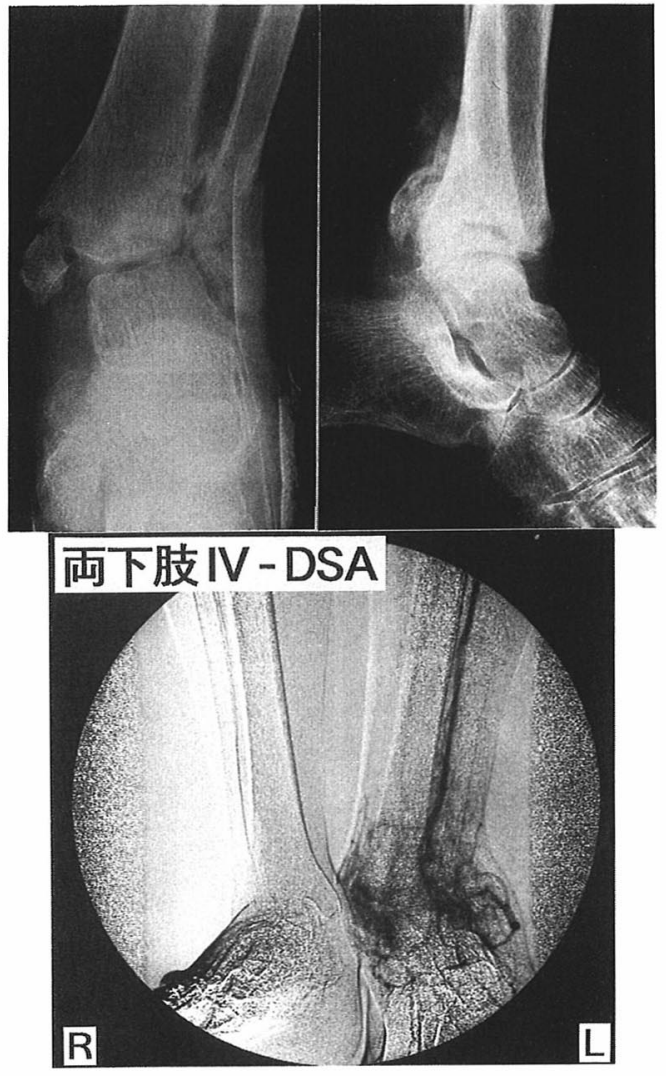

図 1 症例 1 初診時 X線像と両下肢 IV-DSA 像.

関節は変形治療している.

症例 2, 46 歳 女性

主訴; 右膝関節の不安定性

現病歴 脊椎破裂のため両下肢不全麻盘があった。 4 年程前より右膝の動摇性に気ずいた。 1 年程前より 関節水腫が著明となり, 一時は最高 $400 \mathrm{ml}$ も関節液 が貯留されていた．昨年 3 月外反变形が強く歩行障害 をきたし当科を受診した，入院時のレ線像では，外顆 部の骨破壊が著明で高度の不安定性を示し，FTA が $159^{\circ}$ であった。

現症 末梢優位の両下肢知覚低下と右滕腫脹，熱感 を軽度認め, 運動時痛も軽度伴っていた，両下肢 IVDSA で右下肢の異常所見より，春椎破裂によるChar$\cot$ 関節と診断した。

治療は関節固定術を施行した，諸家 ${ }^{5)}$ の報告による と Charcot 関節の観血的治療は関節固定が第一選択
であるが，骨癒合率が 50 60\%であることから，十 分考慮して行った. 術後 4 力月間創外固定後, 骨瘉合 を獲得し現在に至っている.（図 2)

症例 3,59歳 女性 主訴: 歩行不能

現病歴 10 年前より某医で RA にて加療されてい た. 昨年 1 月頃上り両膝関節痛が強く右膝外反变形, 左膝内反変形を呈し立位不能となり当科を紹介された. レ線上骨破壊が著明で Charcot 関節を思わせる所見 であった。

入院時現症, 知覚低下はなく, 両㮏の不安定性著明 であった，ROM は 0 140 で両下肢筋力は fair〜 good level であった. IV-DSA で Charcot 関節に 見られる異常陰影は認められなかった。

治療は両膝に TKR を施行し, 現在経過は良好で杖 にて歩行可能となっている.（図 3)

\section{考察}

Charcot 関節は中枢及び末梢神経障害に伴う破壊 性，増殖性の関節症である。Charcot 関節の特徵と して, 高度の関節破壊, 著明な異常可能性, 著しい関 節水腫があるが無痛性で関節拘縮がないことなどが一 般に挙げられる。しかし, 諸家 ${ }^{6)}$ の報告によると疼痛 を呈する症例も少なくない，また，病期によっては典 型的でなく鑑別診断に困難を伴う場合がある ${ }^{3 / 4)}$ ．実 際，自験例においても程度の差はあれ疼痛を伴ってお り診断に苦虑した。

我々は, 破壊性関節に対し IV-DSA による両下肢 同時撮影を施行している。 Charcot 関節において は, 健側に比べ静脈相陰影が早期より描出され tumor stain 様像を呈する。これは 1971 年 Drennan ら” が Charcot 関節の一つの成因として, 肥厚緎維化し た滑膜内の毛細血管圧が高くなり arterio-venous anastomosis ができ，本来骨軟骨に供給される血液 が anastomosis を流れるため，骨軟骨が栄養されず 骨破壞が進行すると述べた説に一致すると思われた． 以上のことょり，IV-DSA は簡便で患者にとって負 担が少なく，Charcot 関節を疑えば，施行するのが 望ましい診断法を考える.

\section{ま と め}

(1)最近, 我々は下肢破壊性関節 3 症例を経験した。

(2) Charcot 関節の補助診断として IV-DSA 両肢同 


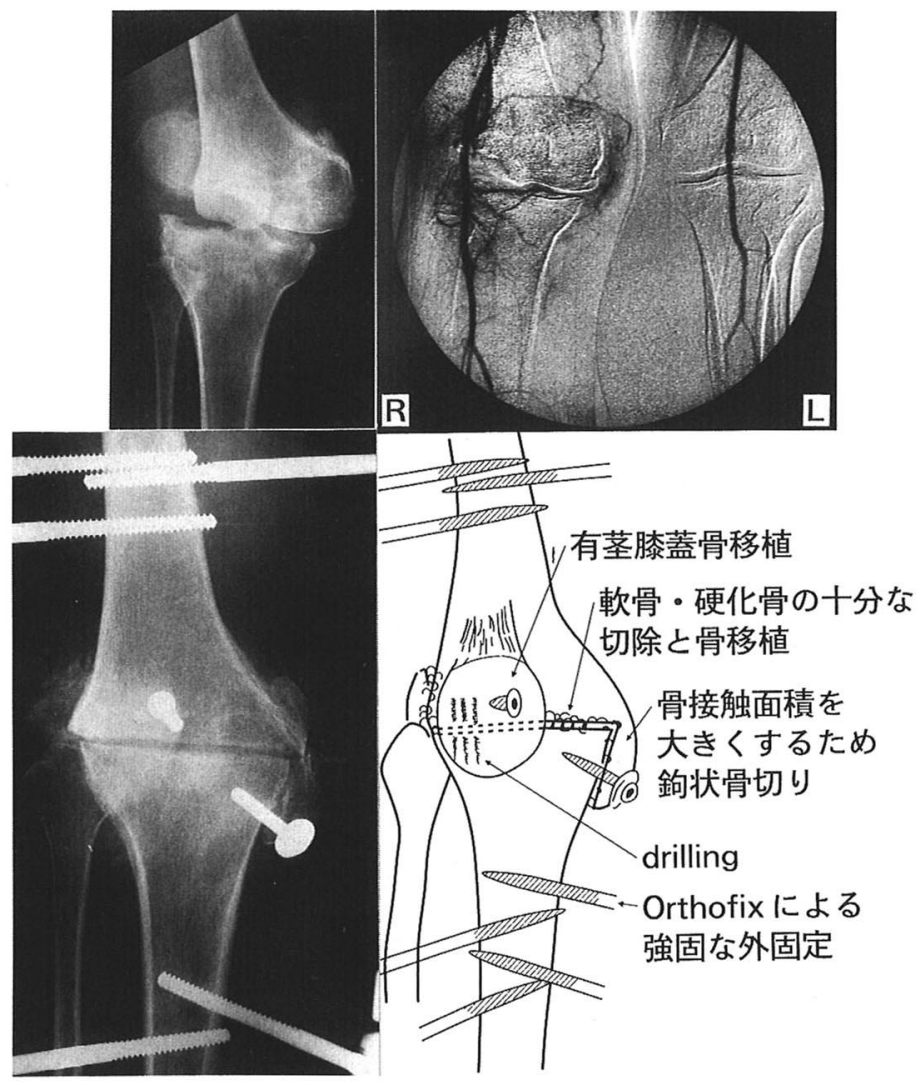

図2 症例 2 術前X線と両下肢 IV-DSA 像および 術後X線像とそのシェーマ.
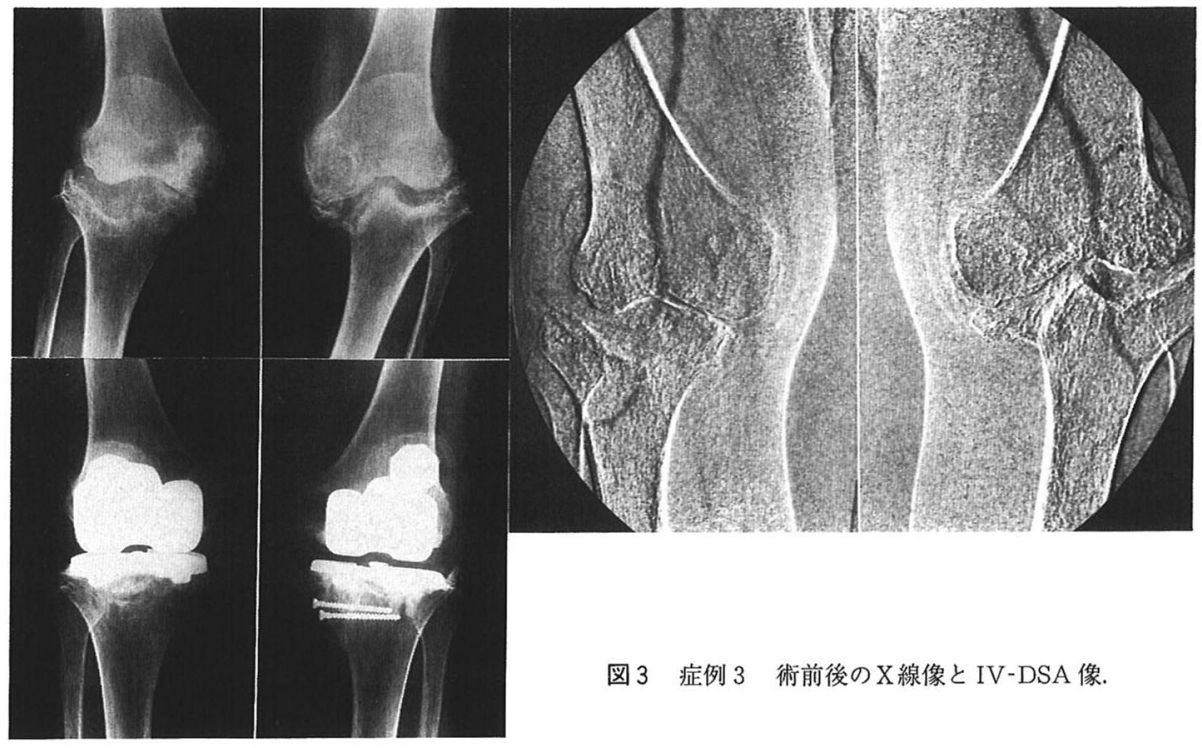

図 3 症例 3 術前後のX線像と IV-DSA 像. 
時撮影が有益であった。

\section{参 考 文 献}

1) D.B. Drennan, et al.: Important Factors in Achieving Arthrodesis of the Charcot Knee. J.B.J.S., 53-A : 1180-1193, 1971

2) S. V. Edelman, et al.: Neuro-osteoarthropathy (Charcot's Joint) in Diabetes Mellitus Following Revascularization Surgery. Arch Intern, Med., 147 : 1504-1508, 1987.

3）広畑和志: 神経障害性膝関節症の診断と治療における 問題点と考察. 臨整外, $22: 238-252,1987$.

4）栗原 章: 神経病性関節症. 整形外科, 35:1739-1743, 1984.

5）森下 裕, 他 : シャルコー膝関節症に対する血管柄付 骨移植を用いた関節固定術，整・災外，1：855-858, 1988.
6）吉田修之, 他 : シャルコー関節の関節水腫, 関節の外 科, $13: 43-48,1986$

質 問東京労災病院 伊地知正光

DSA 所見ですが，スライドのコントロールは RA 例で, negative 所見でしたが，特にCharcotではな く, 少し破壊程度のつよい OA では, どうでしょう か.

解 答 国立善導寺病院 中野 俊次

シャルコー関節のような著明な関節破壊が生じた OA は経験しておらず，IV-DSA の経験はない。 